\title{
La aventura poética de Ricardo Silva-Santisteban
}

\author{
Marco Martos Carrera \\ Universidad Nacional Mayor de San Marcos \\ mmartoscarrera@yahoo.com
}

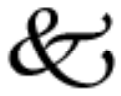

Múltiple es la actividad intelectual de Ricardo Silva-Santisteban. Me complace describirlo, en primer lugar, como poeta y, dentro de esta categoría humana y literaria, quisiera señalarlo, atendiendo a una clasificación literaria medieval, como un clérigo, alguien dedicado a la creación, al estudio y la difusión de las letras y las ciencias humanas.

Durante varias décadas de trabajo intelectual, como estudiante y como profesor, como editor y como amante de las letras, Ricardo Silva-Santisteban ha vinculado su trabajo principalmente a dos casas académicas: la Universidad Nacional Mayor de San Marcos, donde obtuvo su doctorado y donde es querido y apreciado, y la Pontificia Universidad Católica del Perú, donde aparte de sus actividades de profesor del Departamento de Humanidades en la sección de Literatura, tiene a su cargo las magnificas ediciones del Rectorado de esa institución que son ciertamente, como el título de una de sus colecciones, un manantial oculto que contribuye a mantener viva la sensibilidad literaria de la sociedad peruana.

No es propósito de esta presentación dar una ficha bibliográfica o un cúmulo de datos sobre la actividad intelectual de Ricardo Silva-Santisteban, pero sí señalar que como estudioso de la literatura, como hombre de letras, es autor de numerosos estudios literarios reunidos en 1989 en su libro Escrito en el agua y del trabajo monumental sobre Stéphane Mallarmé de 1998, titulado Stéphane Mallarmé en castellano que incluye la traducción prácticamente de todos los escritos del gran innovador de la poesía francesa. Como si esto le 
pareciera poco, Ricardo Silva-Santisteban ha traducido a numerosos autores ingleses y franceses y ha editado antologías de poetas, narradores y dramaturgos peruanos. Particular mención merecen sus ediciones de la poesía, la narrativa y el teatro de Cesar Vallejo que aparte del profesionalismo con que están hechas, son señal clara del afecto que siente por el gran poeta de Santiago de Chuco.

Como lírico Ricardo Silva-Santisteban ha publicado los siguientes poemarios: Terra incógnita (1975), Sílabas de palabra humana (1978), La eternidad que nunca acaba (1985), Río de primavera, cascada de otoño (1988), Junto a la puerta de fuego (1992), Fuego de tu fuego (1994), En el laberinto (1996), Ajuste de cuentas (2000). En dos ocasiones, en 1989 y en $2001^{1}$ ha reunido su poesía bajo el título genérico de Terra incógnita, el titulo de su primer volumen de 1975. Las páginas que siguen estarán dedicadas a hacer una cala en la poesía, el centro de su actividad, como queda dicho.

Melanie Klein, la célebre discípula de Sigmund Freud, ha señalado que el ser humano tiene dos maneras básicas de relacionarse con su entorno: o permanece ligado a la tierra en la que nace, donde han vivido sus ancestros, o se deja ganar por el deseo de aventura, de internarse en lo desconocido, que está también en sus genes. El hombre o es sedentario o es aventurero o alterna estas tendencias o deja una para preferir otra. Se dice, por ejemplo, que el hombre es aventurero en su primera edad y se va tornando sedentario cuando avizora la senectud. Para Klein, lo sedentario del individuo lo liga con la madre y el espíritu aventurero es la marca de lo paterno. En el campo literario, en las primeras décadas del siglo XX, Guillermo de Torre hablaba de la aventura y el orden, el afán de cambio y el afán de permanencia, la vanguardia y la tradición como fenómenos complementarios. Para examinar la poesía de Silva-Santisteban, la primera pregunta que nos hacemos es la razón por la que un titulo primigenio Terra incógnita permanece a lo largo de décadas y es escogido como lema para toda su producción lírica. La respuesta, siendo compleja, admite hipótesis de que se está hablando de la propia

1 Ricardo Silva-Santisteban. Terra incógnita. Lima, Pontificia Universidad Católica, 2001. 
poesía. Dedicarse a ella es emprender una aventura, una exploración que dura toda la vida. La poesía es territorio inagotable, infinito, variado, misterioso, fuente de inspiración y de riesgo. Así el poeta ha escrito en la página liminar de su poesía completa:

\section{Poiesis}

Al huir del correr de mi sangre

Te persigo en el polvo

En las arenas

Y en los ríos

En imágenes subiendo y descendiendo por el aire

Con pájaros enloquecidos

Árboles sin hojas

Hojas sin palabras

Persigo la implacable sucesión de lo concreto

Cuando retorno al ser primario

Para escuchar el rumor de los manantiales interiores

Creo por tanto en la posesión de los cuerpos

Y en la extinción de las almas

En el temblor de la luz

Cuando despunta el sol de un nuevo día

Ven pues multitud de sonidos

Y quiébrate en mil aristas del sol y de la lluvia

Mi demonio Poesía

Una forma de entender el derrotero poético de Ricardo Silva-Santisteban es, tal como lo hace Ricardo González Vigil en su Antología de la Poesía Peruana del siglo XX de 1999, señalar que la organización de Terra incógnita sugiere una travesía desde el caos prenatal que, pasando por el desarrollo corporal y anímico, por la comunión con la mujer y la materia, arriba a las tinieblas inexploradas del misterio. González Vigil subraya, además, que en el poemario Sílabas de palabra humana, sobresalen los nexos entre el fuego cosmológico del tiempo primordial que incluye la reelaboración del pasado andino, el fuego del orgasmo erótico y el apocalipsis presentido. Pareciéndonos verdaderas las consideraciones de González Vigil, quisiéramos enmarcarlas dentro de otras perspectivas más generales, si tenemos 
en cuenta que para Ricardo Silva-Santisteban la poesía es la actividad central de su vida, el fuego nutricio que da calor e ilumina a todas las demás acciones que emprende.

Desde el Renacimiento hasta nuestros días, los poetas se han ubicado de distinta manera en la sociedad que los cría y acoge. Un lírico como Garcilaso, fue, al mismo tiempo, el modelo español del cortesano, alguien que ora tomaba la pluma, ora la espada, ora la vihuela, ora conversaba con los dignatarios o con las damas. Pasados varios siglos, un escritor como Víctor Hugo se preciaba tanto de tener una actividad pública como hombre de Estado, como de sus novelas y poemas. Pero un Baudelaire, ya es un adelantado de lo que ocurriría después con los líricos. Sin un papel definido en el contexto de la sociedad, el poeta y la poesía se vuelven sobre sí mismos y dejan de alimentar aquello que Northrop Frye, ha llamado el mito de incumbencia. Puede decirse que Walt Whitman es, en el siglo XIX, el último gran poeta que expresa el mito de la incumbencia que no es otra cosa que la convicción de la pertenencia a una nación que atraviesa todo su libro Hojas de hierba. En el siglo XX, el mito de la incumbencia ha sido expresado sobre todo por los líderes políticos, y los poetas. Cuando han cantado a una causa, lo han hecho solamente en los momentos de gran agitación política o en el marco de las revoluciones. Mallarmé es el mejor ejemplo que se puede señalar de lírico exclusivamente centrado en su actividad, ajeno a los grandes mitos, a las consideraciones teleológicas. Se le puede considerar como fundador de una estirpe lírica de poetas que si bien son herederos del romanticismo y del parnasianismo, tienen otra manera de vincularse con el texto. Por comodidad los llamamos simbolistas, pero van más allá de los estrechos marcos de esa escuela. Mallarmé crea un tipo de poesía que difumina el yo creador, que lo deja sin biografía evidente, en ese sentido se aleja del romanticismo, y dando gran preponderancia a la forma, no atiende tanto a la secuencia rítmica de los acentos como los parnasianos, como al rigor de las imágenes y al misterio de los símbolos. No hace Mallarmé, una poesía incomprensible y estrambótica. Como Luis de Góngora en otro tiempo, deja claves 
suficientes para penetrar en el centro de su pulpa linguiística. Si el poeta en otros siglos miraba a los grandes horizontes y cantaba a los mitos de la libertad, la fraternidad y la igualdad, Mallarmé reduce su mirada al entorno de una habitación, de una biblioteca, al salón de la tertulia, donde quedos los objetos amados esperan la palabra del poeta que los anime y los haga eternos. Mallarme es uno de los lares de la poesía de Ricardo Silva-Santisteban. Otro penate es, sin duda, José María Eguren.

En su "Homenaje a José María Eguren”, que se titula específicamente "19 de abril de 1942", la fecha de la muerte del autor de Simbólicas y La canción de las figuras se dice lo siguiente:

Diecinueve de abril de 1942

Cuando a mí descendía el espíritu de la armonía

las formas de la naturaleza se cruzaban,

celeste y vertiginosamente se cruzaban

renaciendo.

Insecto, planta, viento o surtidor

de pronto me abría su secreto;

descendía mas allá de la caverna de los elfos

y del deterioro de los sentidos.

Aves.

En el cosmos fluía y fluía el mundo cambiante.

Sulcaban peces por remotos espacios, el universo, el tiempo, las formas se borraban.

Aves.

Deleites esenciales. Formas esenciales. Dorada Geometría

Fluía hacia la luz en el Tiempo,

discurría por rutas de reyes o de seres entrevistos a la noche.

Caminaba casi corriendo y sin peso,

el bosque umbroso desplegado a mi vera,

el riachuelo manando sin fin,

por secos manantiales.

Pequeños seres, sendas dormidas,

pájaros fugaces:

en el Tiempo. 
Hay numerosos indicios de la admiración de Ricardo Silva-Santisteban por José María Eguren. Desde la crestomatía que preparó hace algunos años sobre el poeta de los reyes rojos y el duque nuez, hasta varios artículos en revistas especializadas. Eguren trae a la poesía peruana la construcción de espacio de palabras donde en un eterno presente conviven los prados amenos y las mañanas neblinosas, los sueños amables y las pesadillas, la contemplación minuciosa de la campiña y el horror fantasmal de la muerte. Descriptiva y figurativa, vinculada tanto a los grandes poetas románticos y simbolistas, como a la Lima aldeana en la que le toco vivir, solo que de una manera más sutil, la poesía de Eguren, como la de Mallarmé pone entre paréntesis el yo creador y se aleja también de los modelos románticos; de otro lado, Eguren es el primer poeta peruano que prescinde del entorno social. Existen, sin embargo, algunos estudiosos como Jorge Díaz Herrera que se ha preocupado por encontrar en la entrelínea de la poesía de Eguren la presencia de los conflictos sociales de su época. Hasta ellos admiten que en caso de que así fuera, seria en forma de apagados ecos. Lo que hace Eguren, como tantos otros poetas de su estirpe es transfigurar tanto la realidad que apenas es reconocible y como la realidad en la que cree no es solamente la más obvia de los sentidos y de la vida cotidiana, sino aquella otra de los sueños y los juegos, termina por ser una diferente y única que nace por primera vez en ese cenáculo de palabras que llamamos poema.

La poesía de Emilio Adolfo Westphalen, aceptada unánimemente en las últimas décadas, tiene un papel importante en la escritura de Ricardo Silva-Santisteban. Westphalen, como Mallarme y como Eguren, es un poeta que quiere una voz que desea que sus textos fluyan como cascadas de agua. El también prescinde del entorno social para ir al encuentro de los elementos básicos: aire, agua, tierra, fuego. Para Westphalen la poesía es un misterio y la actividad lírica, una manera de vincularse con el mundo. Dicho escuetamente: escribir es sólo una manera de hacer poesía. Casi ignorada en su momento y reconocida a partir de 1980, la poesía de Westphalen, tiene, sobre todo en su segunda fase, otra coincidencia con la de Ricardo Silva- 
Santisteban: el afán erótico que emerge de las profundidades de la experiencia y de la propia lengua. Y en esta preocupación radical, extremada por el erotismo, aparece también otra figura familiar en el santoral de la poesía peruana: Cesar Moro. Y junto a Moro, en la misma bandada de pájaros poetas parientes, inscribimos los nombres de Xavier Abril y de Jorge Eduardo Eielson.

En los comienzos literarios de Ricardo Silva-Santisteban dos amigos poetas de similares inquietudes ocupan un lugar central en su vida cotidiana: Javier Sologuren y Armando Rojas. La aventura literaria que emprendieron juntos, la de la revista Creación y Crítica es testimonio público de aquella cercanía. En una mañana como esta, justo es también rendir homenaje a Armando Rojas, fallecido en 1986, y a Javier Sologuren cuyas dotes personales y cuya calidad literaria son reconocidas por muchos. Javier Sologuren desde sus primeros poemas de 1939 ha ido labrando una poesía de una sostenida originalidad. Si en los poemas de Dédalo dormido de 1947, predominaba el mundo de los sueños, en aquellos otros de Estancias de 1961, a la manera del seráfico Francisco de Asís, se acerca a los elementos de la tierra y a las personas que ama. Javier Sologuren tiene, como el propio Ricardo Silva-Santisteban, una enorme curiosidad, por escritores de otras lenguas, en especial la fascinación por los poetas del oriente. Con mucha naturalidad tomamos que un poeta como Ricardo Silva-Santisteban en colaboración con otros escritores haya intervenido en las traducciones de Omar Jayyam y Li Tai Po, pero se trata de una labor excepcional para la que muy pocos poetas están preparados.

A esta familia literaria formada por Mallarmé, Eguren, Westphalen, Moro, Abril, Eielson, Sologuren, Rojas, a la que bien se pueden agregar los poetas ingleses Keats y Shelley, pertenece Ricardo SilvaSantisteban. Su poesía seria inexplicable sin esos autores, maestros o amigos. Por eso mismo, mayor ha sido la responsabilidad en su búsqueda de la originalidad. Desde sus inicios, la poesía de SilvaSantisteban ha tenido pareja calidad. Ha dejado de lado, como los autores mencionados, la realidad más directa, para vincularse con 
los elementos naturales. En la temática amorosa, de natural frecuentación, la anécdota se oscurece hasta desaparecer y quedar en las puras esencias:

\section{Oración por una mujer \\ Abrázame \\ Como un delirio de sonidos \\ Como la hiedra profunda \\ Y así luego me ames \\ Como el llegar de la noche \\ Y después ya no te apartes \\ Así amémonos de nuevo \\ Como el día siempre es aurora \\ Que luego el polvo nos cubra \\ Y de mí ya no te apartes}

La originalidad en este poema, y por extensión en toda la obra poética de Silva-Santisteban, no hay que buscarla ni en un vocabulario rebuscado, ni lo extremado de las imágenes, ni en la audacia de la sustancia poética. La podemos encontrar, más bien, como en Fray Luis de León, en esa aparente naturalidad del fluir rítmico de los versos, en ese presente eterno, anhelo de perfección y de complementación que inauguran sus palabras. Dentro de su aparente simplicidad, el poema sabe penetrar como una saeta en los entresijos del ser, nos habla de una situación básica universal, aquélla del amor, a ella vuelve y gracias a ella construye una nueva realidad.

En el trabajo de Américo Ferrari que abre las páginas de la última edición de Terra incógnita sabiamente se dice: "La obra poética de Ricardo Silva-Santisteban -treinta y cinco años de escritura lenta y recatada que más que alargarse se ahonda- es una exploración tan lenta como apremiante de unos parajes extraños y familiares a la vez, donde incesantemente se abrazan Eros y Thánatos. La suerte los engendró juntos y hermanos, ha dicho Leopardi en un poema celebre que lleva por título precisamente "Amor y muerte" y análoga visión o sentimiento se percibe también en la poesía de Novalis, de Gérard de Nerval, de Baudelaire. 
No cabe sino coincidir con el ilustre poeta y crítico peruano que amplía, en ese párrafo inicial de su estudio sobre la poesía de SilvaSantisteban, la visión más difundida de la crítica sobre ella. A esta escritura se le ha considerado siempre vinculada al mundo de los sueños y al del erotismo, expresión también de un indefinible purismo. Es cierto que hace varias décadas C. M. Bowra en su hermoso libro La herencia del simbolismo, dilucidó, al estudiar la obra de Rilke, o de Yeats, o de Blok, que estos grandes poetas del siglo XX, que asimilaron tan bien las lecciones del simbolismo, no excluyeron el temblor del individuo, la presencia del dolor, la importancia, en una palabra, de la existencia humana, en el mundo cerrado de palabras que nos han ofrecido. Así ocurre con Silva- Santisteban: su poesía está ligada a la experiencia humana. Y aunque su vocabulario es escogido, como lo es el de Mallarmé o el de Eguren, en el sentido de que excluye palabras altisonantes o modismos o lenguajes especiales, capta la tensión misma de la aventura del hombre. Y hasta puede decirse, si esto no parece un exceso crítico, que alía la herencia del simbolismo con la herencia del expresionismo:

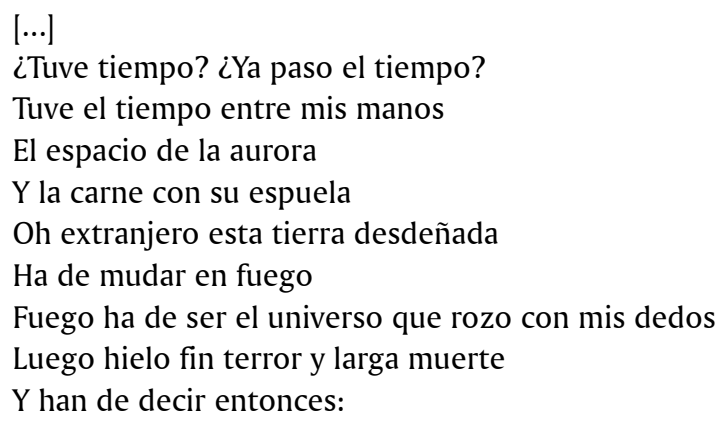


Plumas de gaviotas entre invierno y verano

Lunas cadentes sin posible lamento

Retorno de nuevo hasta alcanzar el fin del mundo

Cierro los ojos y termina el sentido

Mis pies se posan sobre esta arca o esta nave

Mi destino depende de las olas o el viento

Y las palabras resbalan hasta llegar -tal vez- al poema

Comienzo por el fin para alcanzar el principio

Esta es la poesía de Silva-Santisteban: un persistente río de palabras que tiene su manantial oculto en el romanticismo, que bordea el expresionismo, baña las hermosas tierras del simbolismo, se transforma en nube y llueve como fina garúa de Eguren, entra con valentía en el mundo de los sueños y de las pesadillas, avizora la muerte, conoce su paciencia, y regresa, pertinaz, a sus orígenes.

Intelectual de probada dedicación al trabajo, poeta que es un orífice de la palabra en su aventura lírica a lo largo de décadas, Ricardo Silva-Santisteban no ha hecho otra cosa que engalanar nuestra lengua que es la casa de todos. En su estro aventura y orden se complementan y no disputan. Melanie Klein estaría de acuerdo en la afirmación de que quien viaja mucho en poesía, como Ricardo SilvaSantisteban, es el que mejor permanece. 